\title{
Comparative study on chemical composition and antibacterial activity of fenugreek (Trigonella Foenum graecum L.) and cumin (Cuminum cyminum L.) seeds
}

\author{
Hasna Bouhenni ${ }^{1}$, Koula Doukani' ${ }^{1}$, Nazım Şekeroğlu ${ }^{2}$, \\ Sevgi Gezici ${ }^{2}$, Souhila Tabak ${ }^{1}$
}

\author{
1 - University of Ibn Khaldoun, Tiaret, Algeria \\ 2 - Kilis 7 Aralık University, Kilis, Turkey
}

Keywords:

Cumin

Fenugreek

Seed

Antibacterial

\section{Article history:}

Received

27.02.2019

Received in revised

form 14.06.2019

Accepted

28.11.2019

Corresponding

author:

Koula Doukani

E-mail:

kouladoukani@

gmail.com

DOI:

$10.24263 / 2304-$

974X-2019-8-4-7

\section{Abstract}

Introduction. The objective of this study was determination of the physico-chemical characteristics of fenugreek (Trigonella Foenum graecum L.) and cumin (Cuminum cyminum L.) and evaluation of their antibacterial properties against Staphylococcus aureus ATCC25923, Escherichia coli ATCC 25922 and Bacillus subtilis ATCC 6633.

Materials and Methods. Different varieties of fenugreek and cumin were analyzed for their weight of 1000 seeds and germination rate. The physico-chemical analysis carried out was $\mathrm{pH}$, titratable acidity, moisture, ash, total soluble solids, electrical conductivity, viscosity, proteins, fats, crude fibers, pectins, total and reducing sugars and minerals. The antibacterial activity of the extracts was evaluated by disc diffusion method against tested bacterial strains.

Results and discussion. The obtained results showed that the Algerian variety of fenugreek and Syrian one of cumin seeds gave the highest weight with a value of 16.8 and $13.9 \mathrm{~g}$ respectively and the better germination rate with a percentage of $70 \%$. The $\mathrm{pH}$ and titratable acidity of fenugreek and cumin seeds ranged from 5.6 to 6.5 and 2.8 to $3 \%$ respectively. The moisture and ash content varied from 3 to $2.8 \%$ and 3 to $7 \%$ respectively. Total soluble solids, electrical conductivity, viscosity varied from 2.8 to $5.5^{\circ}$ Brix, 18.1 to $42.8 \mathrm{mvs}$ and 2.4 to $2.8 \mathrm{~m} / \mathrm{pa} / \mathrm{s}$ respectively. The analysis showed that fenugreek and cumin contained a high amount of proteins which was between 23.1 and $26.8 \%$. On the other hand, fats ranged from 8.8 to $21 \%$. While crude fibers, pectins varied from 5.1 to $7.9 \%$ and 1.9 to $2.8 \%$ respectively. Total and reducing sugars varied from 5.2 to $6.7 \%$, and 0.5 to $1 \%$ respectively. According to the present data, mineral and heavy metals profile of fenugreek and cumin showed that they contain potassium as a major mineral in a maximum quantity followed by sulphur, phosphorus, calcium, magnesium, iron, zinc and boron, copper, lead, nickel, chromium, molybdenum, cobalt and cadmium. The results of antibacterial activity of methanol extract plants against three bacterial strains revealed the sensitivity of these strains to the extracts plants with DZI (Diameter Zone of Inhibition) of $21 \mathrm{~mm}, 12 \mathrm{~mm}, 18 \mathrm{~mm}$ for cumin and $10 \mathrm{~mm}, 08 \mathrm{~mm}, 09 \mathrm{~mm}$ for fenugreek respectively for $S$. aureus, E. coli and B. subtilis.

Conclusion. The overall evaluation of this study concludes that both spices fenugreek and cumin have good chemical composition and revealed their sensitivity on the tested bacterial strains. 


\section{Introduction}

The World Health Organization [WHO] estimates that 80 percent of the world population use medicinal plants for some aspect of primary health care [1]. Plants showed large spectre of pharmacological activities including anticancer, antimicrobial, cardiovascular, antioxidant, anti-inflammatory, immunological, analgesic and many other pharmacological effects [2]. Spices and herbs have been used for thousands of centuries by many cultures and scientific experiments have documented the antimicrobial properties of spices, many spices are also used for purposes of medicine and in cosmetics, perfumery and liquorices in many parts of the world [3]. Fenugreek and cumin are commonly used spices in very small quantities as a food additive for flavor, color, or as a preservative and therapeutic agent [4].

Fenugreek seed (Trigonella Foenum graecum L.) is an annual herb of the Leguminosae family indigenous to western Asia and South Eastern Europe. It has long been cultivated in the Mediterranean area, in India and in North Africa, and consumed in many forms, it has wide range of characteristics such as aromatic smell, bitter taste, carminative properties, antioxidant and antibacterial benefits, major constituent of fenugreek seed is carbohydrate that accounts for $50 \%$. Other chemical constituents of seed are 3 to $4 \%$ ash, 3 to $5 \%$ moisture, 25 to $30 \%$ protein, 7 to $9 \%$ lipids, 20 to $25 \%$ insoluble fibre [5]. Seeds have $7.5 \%$ lipids that are usually in the form of triglycerides $6.3 \%$ and $450 \mathrm{mg} / 100 \mathrm{~g}$ phospholipids [6]. Fenugreek is used traditionally as a demulcent, laxative, lactation stimulant and exhibits hypocholesterolemic, hypolipidemic and hypoglycemic activity in healthy and diabetic animals and humans, the defatted seeds material of fenugreek may reduce gastrointestinal absorption of glucose and cholesterol and increase bile acid secretion [7].

Cumin is a strong aromatic dried ripe fruit seed of Cuminum cyminum L. It belongs to the Apiaceae family (parsley family), cumin seeds are ancient spices with a strong aromatic smell and warm, bitterish taste. It is widely used as a condiment, it has great medicinal value, is used in traditional medicine to treat flatulence, digestive disorders, and diarrhea and in the treatment of wounds. It is valuable in dyspepsia, diarrhea and hoarseness, and as remedy against indigestion and colic [8]. Physicochemical analysis showed that Cuminum cyminum contained $8 \%$ Moisture, $7.5 \%$ total ash:, $18.4 \pm 0.16 \%$ crude proteins, $21.8 \pm 0.13 \%$ crude fibers and $55.6 \%$ total carbohydrates [9]. The previous pharmacological studies revealed that Cитіпит сутіпит exerted antimicrobial, insecticidal, anti-inflammatory, analgesic, antioxidant, anticancer, antidiabetic, antiplatelet aggregation, hypotensive, bronchodilatory, immunological, contraceptive, anti-amyloidogenic, anti-osteoporotic, protective and central nervous effects [3].

Therefore, the present study was lunched to highlight some chemical, nutritional properties and health benefits of fenugreek (Trigonella Foenum graecum L.) and cumin (Cuminum cyminum L.) seeds and to investigate the bacteriological characteristics of these plants. In this context, a research work was undertaken to elucidate physico-chemical and minerals analysis of fenugreek and cumin, and to estimate the antibacterial activity of their extracts against three bacterial strains ( $S$. aureus, E. coli and B. subtilis) in order to compare the proximate composition and the inhibitory effects of these plants. 


\section{Materials and methods}

\section{Selection of varieties}

Different varieties of fenugreek (Trigonella foenum-graecum L.) and cumin (Cuminum cyminum L.) from Algeria, Egypt, India, Morocco and Syria were purchased from a local market and analyzed for their weight of 1000 seeds and germination rate in order to select the best ones.

Weight of 1000 seeds. The number of seeds taken into by hand count on 100 and 1000 seed weight was measured in $(\mathrm{g} / \mathrm{mg})$ and used to estimate the seed rate based on fixed number of seeds and test weight [10].

Germination Rate. Seeds were treated with dry heat at $50{ }^{\circ} \mathrm{C}$ for 4 days to eliminate residual dormancy that might interfere with germination rate. Two sets of 25 seeds for each cultivar [one from each replication ] were placed on Whatman no. 1 filter paper inside a 9 $\mathrm{cm}$ Petri dish. The filter paper was moistened with $2.5 \mathrm{ml}$ of distilled water, and the seeds were germinated in the dark at $25{ }^{\circ} \mathrm{C}$ and $>97 \%$ relative humidity $(\mathrm{RH})$ inside a germinator. Seeds showing $2 \mathrm{~mm}$ of radicle growth or more were considered germinated. Germination rate was calculated using the following formula and designated as RG index : [11]

$$
\text { Rate of germination }(\mathrm{RG})=\frac{\text { no. of seeds germinated at } 48 \mathrm{~h}}{\text { no. of seeds germinated at } 168 \mathrm{~h}} \times 100
$$

\section{Sample preparation}

The selected samples were sorted, peeled, washed, dried at room temperature, then powdered and screened at $200 \mu \mathrm{m}$.

\section{Physico-chemical analyses}

Physico-chemical analyses: $\mathrm{pH}$, titrable acidity, ash, moisture, viscosity, electrical conductivity, total soluble solids, fibers, fats, proteins, pectins, total and reducing sugars and minerals were estimated according to the following methods:

pH. $10 \mathrm{~g}$ of each fresh sample was added to $100 \mathrm{ml}$ of distilled water, shaking for 10 min and immersing the $\mathrm{pH}$ electrode in the solution [12].

Titratable acidity. $5 \mathrm{~g}$ of each sample was diluted in $25 \mathrm{ml}$ of distilled water and titrated with $\mathrm{NaOH}(0.1 \mathrm{~N})$ until $\mathrm{pH}$ 8.1. [12].

Ash. $10 \mathrm{~g}$ of powder sample was weighed and incinerated at $550{ }^{\circ} \mathrm{C}$ for $6 \mathrm{~h}$ in an ashing muffle furnace until ash was obtained. The ash was cooled and reweighed [12].

Moisture. $10 \mathrm{~g}$ sample was dried at a temperature of $105^{\circ} \mathrm{C} \pm 5$ until weight was constant [12]. 
Viscosity. The viscosity was estimated using viscometer at $20 \mathrm{rpm}$ and $25^{\circ} \mathrm{C}$ [13].

Electrical conductivity. Electrical conductivity expresses the ability of the aqueous solution to conduct an electric current. The conductivity meter electrode was immersed in a $20 \%$ solid solution [14].

Total soluble solids. Total soluble solids [TSS] were directly recorded by digital refractometer and the results were expressed as percent soluble solids ( $\left.{ }^{\circ} \mathrm{Brix}\right)$ [14].

Crude fat. The crude fat was determined using Soxhlet extraction for $6 \mathrm{hrs}$, using $\mathrm{n}$ hexane as a solvent [12].

Crude fibers. $1 \mathrm{~g}$ of powdered sample was digested with $\mathrm{H}_{2} \mathrm{SO}_{4}(1.25 \%)$ followed by $\mathrm{NaOH}[1.25 \%]$ solution. After filtration and washing with distilled water and acetone, remaining residues were weighed and putted in muffle furnace at a temperature of 550-650 ${ }^{\circ} \mathrm{C}$ till grey or white ash was obtained [12].

Crude proteins. The powdered samples of fenugreek and cumin were tested for crude protein content according to the Kjeldahl's method as described in AOAC [12]. Briefly, $2 \mathrm{~g}$ of each sample were digested with $\mathrm{H}_{2} \mathrm{SO}_{4}$ by using digestion mixture (catalyst). The digested material was diluted up to $250 \mathrm{ml}$ in volumetric flask. $10 \mathrm{ml}$ of $\mathrm{NaOH} 40 \%$ as well as $10 \mathrm{ml}$ of digested sample was taken in distillation apparatus where liberated ammonia was collected in beaker containing $4 \%$ boric acid solution using methyl red as an indicator. The percentage of nitrogen in the samples was assessed by titrating distillate against $0.1 \mathrm{~N} \mathrm{H}_{2} \mathrm{SO}_{4}$ solution. Crude protein content was calculated by multiplying nitrogen percent (N\%) with factor (6.25).

Pectins. The extraction of the pectins was estimated by a treatment of samples with high temperature using hydrochloric acid as described by Multon [15]. Pectins were separated from the residue by centrifugation and precipitation with alcohol, the obtained precipitate was filtered to remove soluble impurities, then dried and weighed.

Total sugars. Totals sugars were determined using a colorimetric test according to Dubois [16], using phenol and concentrated sulfuric acid. In brief, $1 \mathrm{ml}$ of sugar solution was added to $1 \mathrm{ml}$ of phenol $5 \%$ and $5 \mathrm{ml}$ of concentrated sulfuric acid, then shaked and placed for 10 to $20 \mathrm{~min}$ in a water bath at 25 to $30^{\circ} \mathrm{C}$. The absorbance was measured at $490 \mathrm{~nm}$. The amount of sugars was determined by reference to a standard curve established with glucose.

Reducing sugars. $1 \mathrm{ml}$ of the sugar solution was removed and $1 \mathrm{ml}$ of DNSA reagent was added after $5 \mathrm{~min}$ of heating in a water at $100{ }^{\circ} \mathrm{C}$, the absorbance reading was made at $540 \mathrm{~nm}$, the results were expressed in relation to a standard curve using glucose as reference [17].

Mineral content. The plant samples were analyzed for their macronutrients $(\mathrm{P}, \mathrm{Ca}, \mathrm{K}$, $\mathrm{Mg}$ and $\mathrm{S}$ ), micronutrients ( $\mathrm{Fe}, \mathrm{Cu}, \mathrm{B}$ and $\mathrm{Zn}$ ) and heavy metals ( $\mathrm{Cd}, \mathrm{Co}, \mathrm{Cr}, \mathrm{Mo}, \mathrm{Ni}$ and $\mathrm{Pb}$ ) by using ICP-AES [18]. Briefly, $0.2 \mathrm{~g}$ of samples were put into burning cup and $5 \mathrm{ml} \mathrm{HNO} 3$ $65 \%$ and $2 \mathrm{ml} \mathrm{H}_{2} \mathrm{O}_{2} 30 \%$ were added. After burning in a HP-500 CEM MARS 5 microwave at $200^{\circ} \mathrm{C}$, the solution was cooled at room temperature for $45 \mathrm{~min}$, filtrated by Whatman 42 filter paper. The extracts were cooled by high-deionized water in a $20 \mathrm{ml}$ polyethylene bottles and kept at $4^{\circ} \mathrm{C}$ for ICP-AES analyses. 


\section{Antibacterial analysis}

Preparation of extracts. The extracts were prepared using maceration method [19].100 $\mathrm{ml}$ of methanol $70 \%$ was added to $10 \mathrm{~g}$ of each sample, the solutions were shaked for $24 \mathrm{~h}$ at room temperature, the mixtures were then filtered using Whatman paper $\mathrm{N}^{\circ} 01$ and evaporated using rotary evaporator. Dried extract was stored in the refrigerator at $4{ }^{\circ} \mathrm{C}$ for further analyses.

Antibacterial activity. The antibacterial activity of the extracts was evaluated by disc diffusion method against three bacterial strains $S$. aureus ATCC25923, E. coli ATCC 25922 and B. subtilis ATCC 6633 [20]. Bacterial strains were inoculated with Muller Hinton broth for $24 \mathrm{~h}$ at $37^{\circ} \mathrm{C}$. The suspensions were standardized using U.V spectrophotometer in order to provide initial cell counts of about $10^{6} \mathrm{CFU} / \mathrm{ml}$, Sterile discs (diameter $6 \mathrm{~mm}$ ) were impregnated with $10 \mu \mathrm{l}$ of fenugreek and cumin extracts of different concentrations (50 and $100 \mathrm{mg} / \mathrm{ml}$ ). Metronidazol was used as standard antibiotic and methanol as negative control. The diameter of the clear zone around the disc was measured and expressed in millimeters as antibacterial activity [21].

\section{Statistical analysis}

The data from chemical composition and antibacterial effect were analyzed with a statistical software program (SPSS version 20). Differences between plants were compared at $\mathrm{P}<0.05$ with ANOVA 1 in order to find the statistically significant differences. The assays were carried out with four repetitions and the results were expressed as mean values and standard deviation.

\section{Results and discussion}

\section{Selection of varieties}

As shown in Table 1, there are significant differences between the weight of 1000 seeds $(\mathrm{g})$ and germination rate of the different varieties.

Table 1

Weight of 1000 seeds and germination rate of different varieties of cumin and fenugreek seeds

\begin{tabular}{|c|c|c|c|c|c|c|}
\hline \multicolumn{2}{|c|}{ Variety } & Algeria & Egypt & India & Morocco & Syria \\
\hline \multirow[t]{2}{*}{ Fenugreek } & $\begin{array}{c}\text { Weight of } 1000 \\
\text { seeds }(\mathrm{g})\end{array}$ & $16.8 \pm 0.25$ & $11.6 \pm 0.2$ & $10.2 \pm 0.03$ & $10 \pm 0.2$ & $10 \pm 0.000$ \\
\hline & $\begin{array}{c}\text { Germination } \\
\text { Rate }(\%)\end{array}$ & $70 \pm 0.000$ & $40 \pm 0.066$ & $30 \pm 0.25$ & $20 \pm 0.75$ & $20 \pm 0.045$ \\
\hline \multirow[t]{2}{*}{ Cumin } & $\begin{array}{c}\text { Weight of } 1000 \\
\text { seeds }(\mathrm{g})\end{array}$ & $10.1 \pm 0.033$ & $09.8 \pm 0.1$ & $13.6 \pm 0.04$ & $10.2 \pm 0.00$ & $13.9 \pm 0.111$ \\
\hline & $\begin{array}{c}\text { Germination } \\
\text { Rate }(\%)\end{array}$ & $40 \pm 0.05$ & $20 \pm 0.3$ & $60 \pm 0.05$ & $40 \pm 0.05$ & $70 \pm 0.025$ \\
\hline
\end{tabular}




\section{Physicochemical analysis}

Table 2 showed the proximate chemical composition of fenugreek and cumin seeds; No significant differences $(\mathrm{p}>0.05)$ were observed between the parameters.

Results of physicochemical analysis of fenugreek and cumin seeds

Table 2

\begin{tabular}{|l|c|c|}
\hline \multicolumn{1}{|c|}{ Parameters } & Fenugreek & Cumin \\
\hline $\mathrm{pH}$ & $5.6 \pm 0.0075$ & $6.5 \pm 0.0075$ \\
\hline Titrable acidity (\%) & $3 \pm 0.00$ & $2.8 \pm 0.00$ \\
\hline Moisture (\%) & $3 \pm 0.0005$ & $5.6 \pm 0.00$ \\
\hline Ash (\%) & $3^{ \pm} 0.00$ & $7^{ \pm} 0.00$ \\
\hline TSS ( ${ }^{\circ}$ Brix) & $2.8 \pm 0.82$ & $5.5^{ \pm} 0.00$ \\
\hline Electrical conductivity (mvs) & $18.1 \pm 0.005$ & $42.8 \pm 0.00$ \\
\hline Viscosity (m/pa/s) & $2.8 \pm 0.0003$ & $2.4 \pm 0.0009$ \\
\hline Proteins (\%) & $26.8 \pm 0.063$ & $23,1 \pm 0.25$ \\
\hline Fats (\%) & $8.8 \pm 0.34$ & $21 \pm 0.00$ \\
\hline Fibers (\%) & $5.1 \pm 0.00$ & $7.9 \pm 0.00$ \\
\hline Pectins (\%) & $1.9 \pm 0.00$ & $2.8 \pm 0.0033$ \\
\hline Total sugars (\%) & $6.7 \pm 0.0066$ & $5.3 \pm 0.00$ \\
\hline Reducing sugars (\%) & $0.5 \pm 0.00$ & $1 \pm 0.0033$ \\
\hline
\end{tabular}

The macronutrients, micronutrients and heavy metal contents of cumin and fenugreek seeds were given in Table3. Analysis of the mineral contents showed no significant differences between cumin and fenugreek.

Results of minerals analysis of fenugreek and cumin

Table 3

\begin{tabular}{|c|c|c|c|}
\hline & & \multicolumn{2}{|c|}{ Plant } \\
\hline Minerals (mg/kg) & & Fenugreek & Cumin \\
\hline \multirow{4}{*}{ Macronutrient } & $\mathrm{Ca}$ & $1445 \pm 68$ & $8077 \pm 89$ \\
\cline { 2 - 4 } & $\mathrm{K}$ & $10605 \pm 555$ & $14647 \pm 501$ \\
\cline { 2 - 4 } & $\mathrm{Mg}$ & $1229 \pm 88$ & $2610 \pm 111$ \\
\cline { 2 - 4 } & $\mathrm{P}$ & $5143 \pm 366$ & $3817 \pm 321$ \\
\cline { 2 - 4 } & $\mathrm{S}$ & $2648 \pm 135$ & $3423 \pm 211$ \\
\hline \multirow{4}{*}{ Micronutrient } & $\mathrm{B}$ & $11.8 \pm 0.06$ & $22.1 \pm 0.14$ \\
\cline { 2 - 4 } & $\mathrm{Cu}$ & $9.9 \pm 0.4$ & $10 \pm 0.5$ \\
\cline { 2 - 4 } & $\mathrm{Fe}$ & $91 \pm 6$ & $133 \pm 8$ \\
\cline { 2 - 4 } & $\mathrm{Zn}$ & $30.9 \pm 1.5$ & $37.8 \pm 1.8$ \\
\hline \multirow{5}{*}{ Heavy metal } & $\mathrm{Cd}$ & $0.03 \pm 0.002$ & $0.1 \pm 0.008$ \\
\cline { 2 - 4 } & $\mathrm{Co}$ & $0.2 \pm 0.004$ & $0.2 \pm 0.000$ \\
\cline { 2 - 4 } & $\mathrm{Cr}$ & $0.2 \pm 0.007$ & $1 \pm 0.009$ \\
\cline { 2 - 4 } & $\mathrm{Mo}$ & $2 \pm 0.900$ & $0.3 \pm 0.009$ \\
\cline { 2 - 4 } & $\mathrm{Ni}$ & $1.3 \pm 0.90$ & $1.5 \pm 0.11$ \\
\cline { 2 - 4 } & $\mathrm{Pb}$ & $0.4 \pm 0.00$ & $1.4 \pm 0.10$ \\
\hline
\end{tabular}




\section{Antibacterial activity}

The results of antibacterial activity of fenugreek and cumin extract against three bacterial strains ( $S$. aureus, E. coli and B. subtilis) revealed the sensitivity of these strains to the plants extracts as shown in Table 04. In the dose response study, the inhibition zone increased with increasing concentration of the extracts.

Results of antibacterial analysis of fenugreek and cumin

Table 4

\begin{tabular}{|c|c|c|c|}
\hline Plant & & ZI (mm) & \\
\hline \multirow{5}{*}{ Fenugreek } & Strains & $50 \mathrm{mg} / \mathrm{ml}$ & $100 \mathrm{mg} / \mathrm{ml}$ \\
\hline & Concent & & \\
\hline & S. aureus & $07 \pm 0.003$ & $10 \pm 0.004$ \\
\hline & E. coli & $06 \pm 0.05$ & $08 \pm 0.0075$ \\
\hline & B. subtilis & $07 \pm 0.4$ & $09 \pm 0.05$ \\
\hline \multirow{3}{*}{ Cumin } & S. aureus & $11 \pm 0.06$ & $21 \pm 0.333$ \\
\hline & E. coli & $07 \pm 0.08$ & $12 \pm 0.66$ \\
\hline & B. subtilis & $10 \pm 0.0002$ & $18 \pm 0.075$ \\
\hline
\end{tabular}

Our results illustrate that cumin extracts displayed the highest inhibitory effects compared to fenugreek.

\section{Discussion}

\section{Physicochemical composition}

The choose of varieties depended on the results of weight of 1000 seeds $(\mathrm{g})$ and germination rate $(\%)$ of different varieties of fenugreek and cumin, the results showed that the Algerian variety of fenugreek was the best one comparing to the other varieties with a weight of $16.8 \pm 0.25 \mathrm{~g}$ and germination rate of $70 \pm 0.000 \%$, while the Syrian variety of cumin present the higher weight with an amount of $13.9 \pm 0.111 \mathrm{~g}$ and germination rate with percentage of $70 \pm 0.025 \%$.

The result of $\mathrm{pH}$ in fenugreek was lower in comparison with the results of Ahmed Dilshad [22] which were in the range of 6.8 and 6.9, however our $\mathrm{pH}$ value of cumin was significantly lower to the earlier research of Al-Snafi [3] which was 7.3 and higher than results of Monojit [23] which were 3 . The $\mathrm{pH}$ determined for the two spices taken into consideration is in the range of 6-7, which shown slight acidic character. Otherwise differences on $\mathrm{pH}$ can be due to the diversity of the variety, the growing conditions, the degree of ripening and climate [24].

Concerning Titratable acidity, Tabaestani [25] found that cumin posses a lower value of titratable acidity in confrontation with our results which was $0.7 \pm 0.09$. The differences on $\mathrm{pH}$ and titratable acidity could be due to the lower water content as well as to different growing conditions [24].

The percentage of moisture content in fenugreek was similar to those of Abdelmoneim [26] which were $4 \%$ and significantly higher than the results of Udayasekhara [27] which 
were $2.4 \%$. However, cumin revealed very low percentage of moisture compared to the results of Al-Snafi [3] which were $8 \%$. The variations in moisture content reported by various investigators could be attributed to the differences in the environmental conditions, the time of harvesting and the storage conditions [28].

Awais [29] showed a similar amount of ash in fenugreek with our results; 3.4\%, and lower than those of Abdelhamid [30], with a value of 7.6\%. Concerning cumin, it was observed that it presents a high content of ash in contrast to Al-Snafi [3] results which were 6.5, while the present result was similar to those presented by Monojit [23] which were 7.5\% and lower than the maximum limits indicated by the Egyptian Specification Standards [ES: 1930/2008] and by the International Standards Organisation [ISO 9301/2003 ] which was $8.5 \%$ and $12 \%$ respectively. The variation in the ash content could be due to the soil conditions [28].

Total Soluble Solids contents in cumin was higher than fenugreek, regarding fenugreek our results was lower than those of Abdelnabey [31] which were $3.5^{\circ}$ Brix, while Tabaestani [25] found that cumin TSS contents was higher with $7.7^{\circ}$ Brix. No significant difference was detected on TSS between fenugreek and cumin $(\mathrm{p}=0.000)$.

For the viscosity, Brummer [32] found that fenugreek viscosity was significantly higher than the present result $9.6 \mathrm{~m} / \mathrm{pa} / \mathrm{s}$. while cumin viscosity value was lower than Nazima [33] result $0.3 \pm 0.009 \mathrm{~m} / \mathrm{pa} / \mathrm{s}$, Juszczak [34] experiments show that the values of viscosity depend strongly on soluble solids content, the viscosity changed with higher soluble solids content.

Electrical conductivity of cumin was higher than fenugreek, Fred [35] found that cumin present a higher value than the present study 35.1 mvs. The results of specific conductivity indicate that the ash alone was not the cause of the conductivity, but that the organic compounds were concerned [35].

The crude proteins level of fenugreek was approximately comparable to those of Mullaicharam [36] with a value of $25.9 \%$, however our result was significantly higher than those of Fahad [37] with values of $12.9 \%$.

The found protein content amount in cumin seeds were higher compared to those reported in literature of Al-Snafi [3], Monojit [23] which was $18.4 \% \pm 0.16$ and $18.4 \%$ respectively. The difference on crude protein content between plants may be due to different cultural practices, soil and environmental conditions [28].

Suleiman [28] evaluated the chemical composition of fenugreek and concluded that crude fats contents were similar to the presented result with an amount of $8.1 \%$, Also our result was higher than those of Abdelmoneim [26] with a percentage of $4 \%$. While, fats contents in cumin found by Muhammad Sultan [38] was higher with percentage of $31.2 \%$, in the present data the level of fats was approximately similar to the studies of Mengmei [39] with an amount of $22.7 \%$. According to Abdelmoneim [26] the percentage of total lipids of plants differs according to the location and conditions of cultivation.

Many studies have been carried out to estimate the amount of fibers present in fenugreek. Haram [40] present a higher percentage of fibers $13 \%$. while pectins content in fenugreek was lower than Anita [41] result which was 3\%. Fiber contents in cumin were significantly lower in comparison with other studies of Peter [8] with an amount of 30\%, however pectins percentage was higher than Mengmei [39] result which was $1.7 \%$. There is evidence that crude fibers has a number of beneficial effects related to its indigestibility in the small intestine [42].

Sugars analysis expressed that the percentage of total sugars in fenugreek was significantly higher than that showed by Elmahdy and Elsebaiy [43] which was $4.2 \%$. On the other hand, it was lower than the results presented by Anita [41] with an amount of $8.8 \%$, While reducing sugars in fenugreek were similar to the result of Rajini [44] which were $0.5 \%$ 
and lower than Anita [41] result; 0.8\%. Concerning cumin, significant differences in total sugars content were also observed compared to previous studies of Kumar [45] which were 2.4\%. Reducing sugars contents in cumin was similar to those found by Kumar [45] which were $1.2 \%$. The nutritional composition of plants depends on climatic conditions, geographic origin of seeds and cultural practices [46].

According to the present data, mineral and heavy metals profile of fenugreek showed that it contains potassium as a major mineral in a maximum quantity followed by sulphur, phosphorus, calcium, magnesium, iron, zinc and boron, for the heavy metals the higher percentage was their of copper followed by lead, nickel, chromium, molybdenum, cobalt and cadmium. Extensive research has been carried out to determine the amount of mineral elements in fenugreek, and results of Magboul [47] were higher than our results with a value of calcium $(158 \mathrm{mg} / 100 \mathrm{~g})$, phosphorous $(415 \mathrm{mg} / 100 \mathrm{~g})$, iron $(22.5 \mathrm{mg} / 100 \mathrm{~g})$, sodium (493 $\mathrm{mg} / 100 \mathrm{~g})$, magnesium $(1550 \mathrm{mg} / 100 \mathrm{~g})$, potassium $(1306 \mathrm{mg} / 100 \mathrm{~g})$, copper $(331 \mathrm{mg} / 100 \mathrm{~g})$ and zinc $(9.9 \mathrm{mg} / 100 \mathrm{~g})$. The levels of $\mathrm{Cu}, \mathrm{Fe}, \mathrm{Mn}$ and $\mathrm{Zn}$ were higher than the levels given by Ozkutlu [48] $(9 \pm 0.6 \mathrm{mg} / \mathrm{kg}),(36 \pm 3.6 \mathrm{mg} / \mathrm{kg}),(8 \pm 1 \mathrm{mg} / \mathrm{kg})$ and $(19 \pm 0.9 \mathrm{mg} / \mathrm{kg})$ respectively except $\mathrm{Cd}$ which was higher than our result $(0.1 \pm 1.6 \mathrm{mg} / \mathrm{kg})$. Fenugreek seeds are good source of minerals that helped in a number of physiological functions of body and maintains health status [7]. Although they are required in very low quantities because some trace elements heavy metals including iron, copper, zinc and manganese are essential micronutrients with one or more structural or functional roles for living organisms [49]. The present study showed that cumin contains potassium as major mineral followed by calcium, phosphorus, sulphur, magnesium, iron, zinc, boron, copper, lead, chromium, nickel, cobalt, cadmium, molybdenum respectively. Al-Snafi [3] reported a very lower value compared to our results, potassium $(35.8 \mathrm{mg} / 100 \mathrm{~g})$ was being the most abundant element in cumin followed by calcium $(18.6 \mathrm{mg} / 100 \mathrm{~g})$, phosphates $(10 \mathrm{mg} / 100 \mathrm{~g})$, magnesium $(7.3 \mathrm{mg} / 100 \mathrm{~g})$, sodium $(3.4 \mathrm{mg} / 100 \mathrm{~g})$, iron $(1.3 \mathrm{mg} / 100 \mathrm{~g})$, manganese $(0.1 \mathrm{mg} / 100 \mathrm{~g})$, copper $(0.1 \mathrm{mg} / 100 \mathrm{~g})$, selenium $(0.1 \mathrm{mg} / 100 \mathrm{~g})$ and Zinc $(0.1 \mathrm{mg} / 100 \mathrm{~g})$. The amounts of $\mathrm{Cu}, \mathrm{Fe}, \mathrm{Mn}$ and $\mathrm{Zn}$ in cumin reported by Ozkutlu [48] was lower with an amount of $(8 \pm 0.3 \mathrm{mg} / \mathrm{kg}),(129 \pm 2.1 \mathrm{mg} / \mathrm{kg})$, $(14 \pm 0.8 \mathrm{mg} / \mathrm{kg})$ and $(22 \pm 0.5 \mathrm{mg} / \mathrm{kg})$ respectively except $\mathrm{Cd}$ which was higher $(77 \pm 1.3$ $\mathrm{mg} / \mathrm{kg}$ ). Januz [50] indicated that the plants collected from rural areas or grown in less industrialized regions had lower contents of heavy metals than those growing in industrialized regions.

Statistically, there is no significant difference between fenugreek and cumin in term of all parameters $(\mathrm{P}>0.05)$ except cobalt $(\mathrm{P}=0.345)$, Significant differences might be due to the great heterogeneity in the species studied, plant parts used and growing regions [48].

\section{Antibacterial activity}

In the present study, antibacterial activities of methanolic plants were based on the concentration of the extracts. while $100 \mathrm{mg} / \mathrm{ml}$ of methanolic fenugreek extract inhibited E.coli with DZI of $09 \mathrm{~mm} \pm 0.05$, the same concentration inhibited B.subtilis with $08 \mathrm{~mm} \pm 0.0075$ and S.aureus with $10 \mathrm{~mm} \pm 0.004$. No significant difference was observed between the two plants $[\mathrm{p}=0.003$ ]. Dash [51] found that methanol fenugreek extract was effective in inhibiting the growth of E.coli with DZI of $7 \pm 0.23 \mathrm{~mm}$. However, Ramya Premanath [52] examined the antibacterial activity of fenugreek against E.coli and S.aureus, the strongest antibacterial effect was showed against S.aureus compared to E.coli with DZI of $12 \pm 0.7$ and $9 \pm 0.4$ respectively. It was clear from the present results that methanolic extracts exhibited pronounced activity against all the tested bacteria. The highest antibacterial activity may due to the presence of polyphenols because the phenol content was more in the methanolic extract than in any other solvent extracts. A study by Field [53] has shown that 
antimicrobial properties exhibited by plants could be due to the presence of phenols and flavonoids, while fenugreek seeds may contain higher amount of active components which resulted in higher antibacterial property.

Our obtained results demonstrated that methanolic cumin extract at a concentration of $100 \mathrm{mg} / \mathrm{ml}$ present inhibitory effect on the growth of all tested bacteria with diameter of 21 $\mathrm{mm} \pm 0.333$ for S.aureus, $12 \mathrm{~mm} \pm 0.66$ for E.coli and $18 \mathrm{~mm} \pm 0.075$ for B. subtilis, Sagdic [54] investigated the antibacterial effects of cumin against three strains E.coli, S.aureus and B. subtilis, the results showed that cumin extract don't affect the growth of S.aureus and $B$. subtilis on the other hand it produced bactericidal effect on E. coli $[19 \mathrm{~mm}]$. Nazia Masood [55] found that extracts of cumin inhibited the growth of $S$. aureus, E.coli with a diameter of $8.9 \pm 5.6$ and 23.8 \pm 1.2 respectively. Nazia Masood [55] results suggest that the use of some spice as antimicrobial agents may be exploitable to prevent the deterioration of stored foods by bacteria, as long as the taste impact is acceptable in the targeted foods. The extracts of fenugreek and cumin were found to be effective antibacterial agents against human pathogens. This study paves the way for further attention and research to identify the active compounds responsible for the plant biological activity. Further studies should be undertaken to elucidate the exact mechanism of action by which extracts exert their antimicrobial effect.

\section{Conclusion}

The analytical study of fenugreek and cumin seeds showed that these two plants develop a particular composition including nutrients such as proteins, fats, fibers, sugars and minerals. This work represents the first attempt to compare the chemical composition and biological activities of fenugreek and cumin especially to study their antibacterial effect against $S$. aureus, E.coli and B. subtilis strains. In this context, cumin extracts gave interesting results in terms of theses strains comparing to fenugreek extracts. As a whole, these findings confirm the interesting potential of these two spices as a valuable source of nutriments and energy and as antibacterial agents.

Acknowledgments. The authors would like to sincerely thank the staff of Medicinal and Aromatic Plants Laboratory, Advanced Technology Application and Research Center, Kilis 7 Aralik University (Turkey) for their collaboration, and Dr. Samia Meliani ( Faculty of Nature and Life Sciences, University of Ibn Khaldoun -Algeria) for her statistical analysis and continuous help.

\section{References}

1. WHO (2002), WHO Traditional Medicine Strategy 2002-2005, World Health Organization, Geneva.

2. Al-Snafi A.E. (2015), The chemical constituents and pharmacological effects of Chenopodium album - An overview, International Journal of Pharmacological Screening Methods, 5, pp. 10-17.

3. Al-Snafi A.E. (2016), The pharmacological activities of Cuminum cyminum - A review, IOSR Journal of Pharmacy, 6(6), pp. 46-65. 
4. Anupam S., Sunil K., Kiran K., Deepti S. (2018), Medicinal uses of spices used in our traditional culture, Worldwide Journal of Medicinal Plants Studies, 6(3), pp. 116-122.

5. Shankaracharya N.B., Natarajan C.P. (1972), Fenugreek chemical composition and use, Indian Spices, 9, pp. 2-12.

6. Nayak A.K., Pal D., Santra K. (2015), Screening of polysaccharides from tamarind, fenugreek and jackfruit seeds as pharmaceutical excipients, International Journal of Biological Macromolecules, 79, pp. 756-760.

7. Im K.K., Maliakel B. (2008), Fenugreek dietary fibre a novel class of functional food ingredient, Agro Food Ind. Hi-tech, 19,pp. 18-21.

8. Peter K.V. (2001), Handbook of herbs and spices, Woodhead Publishing Limited Abington Hall, Abington Cambridge, England Vol. 1. pp. 1-332.

9. Moawad S., El-Ghorab A., Hassan M., Nour-Eldin H., El-Gharabli M. (2015), Chemical and microbiological characterization of Egyptian cultivars for some spices and herbs commonly exported abroad, Food and Nutrition Sciences, 6, pp. 643-659.

10. Deivasigamani S., Swaminathan C., (2018), Evaluation of seed test weight on major field crops, International Journal of Research Studies in Agricultural Sciences, 4(1), pp. 8-11.

11. Krishnasamy V., Seshu D.V. (1989), Seed germination rate and associated characters in rice, Crop Sci., 29, pp. 904-908.

12. AOAC. (2000), Official method of analysis. Association of Official Analytical Chemists, 17 th Ed. Maryland. U.S.A.

13. NF EN 12092: Adhesives - Determination of viscosity, (2002).

14. AOAC (2002), Official Methods of Analysis. Association of Official Analytical Chemists, 17th Ed. Gaithersburg.

15. Multon J.L. (1991). Techniques d'analyses et de contrôle dans les industries agroalimentaires, Ed. Tech et Doc-Lavoisier. France, pp. 121-137.

16. Dubois M., Gilles K.A., Hamilton J.K., Rebers P.A., Smith F. (1956), Colorometric method for determination of sugars and related substances, Analytical Chemistry, 28(3), pp. 350356.

17. Miller G.L. (1972), Use of dinitrosalicylic acid reagent for determination of reducing sugars, Analytical Chemistry, 31, pp. 426-428.

18. Sekeroglu N., Meraler S. A., Ozkutlu F., Kulak M. (2012), Variation of mineral composition in different parts of Mahaleb, Asian Journal of Chemistry, 24(12), pp. 5824-5828.

19. Gezici S., Sekeroglu N. (2019), Current perspectives in the application of medicinal plants against cancer: novel therapeutic agents, Anti-Cancer Agent Med. Chem., 19(1), pp. 101111.

20. Kim J.W., Huh J.E., Kyung S.H., Kyung K.H. (2004), Antimicrobial activity of alk(en)yl sulfides found in essential oils of garlic and onion, Food Sci. Biotechnology, 13, pp. 235239.

21. Bauer A. W., Kirby W. M., Sherris J. C., Turck M. (1966), Antibiotic susceptibility testing by a standardized single disk method, Am J Clin. 45, pp. 493-496.

22. Ahmad Dilshad (2017), Physicochemical properties of chemurgic-fenugreek (Trigonella foenum-graecum) herb of different origin, Der Pharma Chemica,9(1), pp. 102-106.

23. Monojit D., Samyak C., Amalesh N., Moulisha B., Pallab K.H. (2017), Pharmacognostic and preliminary physicochemical study of vidangadilouham- an ayurvedic antidiabetic herbomineral preparation, Journal of Ayurvedic and Herbal Medicine, 3(1),pp. 15-26.

24. Ariyama K., Nishida T., Noda T., Kadokura M., Yasui A. (2006), Effects of fertilization, crop year, variety, and provenance factors on mineral concentrations in onions, Journal of Agricultural and Food Chemistry, 54(9), pp. 3341-3350.

25. Tabaestani H., Sedaghat N., Saeedi Pooya E., Alipour A. (2013), Shelf life improvement and postharvest quality of cherry tomato (Solanum lycopersicum L.) fruit using basil 
mucilage edible coating and cumin essential oil, International Journal of Agronomy and Plant Production, 4(9), pp. 2346-2353.

26. Abdel Moneim E., Sulieman Heba E., Ahmed Awad M., Abdelrahim A. (2008),The chemical composition of fenugreek (Trigonella foenum graceum $\mathrm{L}$ ) and the antimicrobial properties of its seed oil, J. of Eng. \& Applied Sci, 3(2), pp. 52-71.

27. Udayasekhara Rao P., Sesikeran M.D.P., Srinivasa R., .Nadamuni Naidu V., Vikas R. (1996), Short term nutritional and safety evaluation of fenugreek, Nutrition Research Nutrition Research, 16(9), pp. 1495-1505.

28. Sulieman A. Elhadi. (1995), Fenugreek supplemented backed products, quality aspects. M. Sc. Thesis, University of Gezira, Wad Medani, Sudan.

29. Awais A, Salem S, A., Kaiser M., Muhammad A. (2015), Fenugreek a multipurpose crop: Potentialities and improvements, Saudi Journal of Biological Sciences, 23, pp. 1-11.

30. Abdel-Hamid M.R., Alalla R.K., Moue Z.N. (1984), Chemical studies on Egyptian fenugreek seed, Ann. Agric. Sc., 29(1), pp. 43-60.

31. Abdel-Nabey A.A., Damir A.A. (1990), Changes in some nutrients of fenugreek (Trigonella Foenum graecum L.) seeds during water boiling, Plant Foods for Human Nutrition, 40 (26), pp. $72-74$

32. Brummer Y., Cui W., Wang Q. (2003), Extraction, purification and physicochemical characterization of fenugreek gum, Food Hydrocolloids, 17, pp. 229-236.

33. Nazima S., Adeel A. (2013), A study on viscosity, surface tension and volume flow rate of some edible and medicinal oils, International Journal of Science, Environment and Technology, 2(6), pp. 1318-1326.

34. Juszczak L., Fortuna T., Kosla A. (2003), Sensory and rheological properties of Polish commercial mayonnaise, Nahrung /Food, 47 (4), pp. 232-235.

35. Fred D. (1902), The electrical conductivity of plant juices; Botanical Gazette, The University of Chicago Press journals, 34(2), pp. 81-92.

36. Mullaicharam A.R., Geetali D., Uma M. (2013), Weight serum cholesterol levels and the nitrogen medicinal values of fenugreek, Biol. Chem. Sci., 4, pp. 130- 134.

37. Fahad Mohammed J., Al-Jasser MS. (2012), Chemical composition and fatty acid content of some spices and herbs under Saudi Arabia conditions, Sci World J., 20(12), pp. 1-5.

38. Muhammad T S., Masood S B., Faqir M A., Amer J. (2009), Influence of black cumin fixed and essential oil supplementation on markers of myocardial necrosis in normal and diabetic rats, Pakistan Journal of Nutrition, 8, pp. 1450-1455.

39. Mengmei M., Taihua M., Hongnan S.,Miao Z., Jingwang C., Zhibin Y.(2015), Optimization of extraction efficiency by shear emulsifying assisted enzymatic hydrolysis and functional properties of dietary fiber from deoiled cumin (Cuminum cyminum L.), Food chemistry, 179, pp. 270-277.

40. Haram M.A. (1991), The protein quality of Sudanese fenugreek seeds. M. Sc.Thesis, University of Khartoum, Sudan.

41. Anita K., Malkit N., Rajbir S. (2006), Proximate composition, available carbohydrates, dietary fibre and anti nutritional factors of selected traditional medicinal plants, J. Hum. Ecol., 19(3), pp. 195-199

42. Aremu M., Olaleke O., Olorunfemi A., Emmanuel T. (2006), A Comparative study on the chemical and amino acid composition of some Nigerian under-utilized legume flours, Pakistan Journal of Nutrition, 5, pp. 34-38.

43. Rafik El-Mahdy A., El-Sebaiy L.A (1982), Effect of germination on the nitrogenous constituents, protein fractions, in vitro digestibility and antinutritional factors of fenugreek seeds (Trigonella foenum graecum L.), Food Chemistry, 8(4), pp. 253-262.

44. Rajni M., Joshi R., Beenu T. (2016), Effect of domestic processing on physico chemical and nutritional quality of fenugreek cultivars, Asian. J. Dairy \& Food Res, 35 (4), pp. 338-344. 
45. Kumar Amit N., Dilipkumar P., Kousik S. (2015), Screening of polysaccharides from tamarind, fenugreek and jack fruit seeds as pharmaceutical excipients, International Journal of Biological Macromolecules, 79, pp. 756-760.

46. Demarne F.E. (1985), Le Geranium rosat, Parfums, Cosmétiques et Aromes, 62, pp. 85-92.

47. Magboul B. I. (1986), Chemical and amino acid composition of fenugreek Seeds grown in Sudan, Food Chemistry, 22, pp. 1-5.

48. Özkutlu F., Kara S.M., Şekeroğlu N. (2007), Determination of mineral and trace elements in some spices cultivated in Turkey, Acta Hortic, 756, pp. 321-328.

49. WHO. (1999), Monographs on selected medicinal plants, World Health Organization, Geneva.

50. National Research Council. (1989), Dietary fiber, in committee on diet and health, Food and Nutrition Board, Commission Life Sciences (Eds.),Diet and health implications for reducing chronic disease risk (pp. 291-309), National Academy Press, Washington.

51. Dash B K., Sultana S., Sultana N. (2011), Antibacterial activities of methanol and acetone extracts of fenugreek (Trigonella foenum) and coriander (Coriandrum sativum), Life Sciences and Medicine Research, 27, pp. 65-72.

52. Ramya Premanath J., Sudisha N.,Lakshmi D., Aradhya S.M. (2011), Antibacterial and antioxidant activities of fenugreek (Trigonella foenum graecum L.) leaves, Research Journal of Medicinal Plants, 5, pp. 695-705.

53. Field JA., Lettinga G. (1992), Toxicity of tannic compounds to microorganisms. In: Hemingway RW, Laks PE, Eds. Plant Polyphenols, Plenum Press, New York, pp. 673-689.

54. Sagdic O., Kuscu A., Ozcan M., Ozcelik S. (2002), Effects of Turkish spice extracts at various concentrations on the growth of Escherichia coli O157:H7, Food Microbiology, 19, pp. 473-480.

55. Nazia M., Ahmed C., Perween T. (2006), Anti-microbial activity of Cinnamomum cassia against diverse microbial flora with its nutritional and medicinal impacts, Pak. J. Bot., 38(1), pp. 1-9. 